\title{
PENERAPAN MODEL PEMBELAJARAN QUANTUM TEACHING UNTUK MENINGKATKAN MOTIVASI DAN HASIL BELAJAR BAHASA INGGRIS KEMAMPUAN MEMAHAMI MATERI TEKS PENYERTA GAMBAR/CAPTION SISWA KELAS XII AKL2 SMKN 1 PANJI SEMESTER GANJIL TAHUN AJARAN 2019/2020
}

\author{
Hari Murdianti \\ SMK Negeri 1 Panji \\ Email: hari_mur12@gmail.com
}

Received: June 3, 2020 Revised: June 8, 2020 Accepted: June 11, 2020

\begin{abstract}
ABSTRAK
Berdasarkan hasil observasi bahwa model pembelajaran yang kurang menarik minat siswa akan menyebabkan motivasi belajar siswa rendah dan hasil belajar siswa kurang maksimal. Hasil observasi kelas XII AKL2 SMK Negeri 1 Panji. Motivasi belajar minat dan perhatian siswa terhadap pelajaran mencapai 49\% dengan kategori tidak aktif, tanggung jawab siswa dalam mengerjakan tugastugas belajarnya mencapai 55\% dengan kategori tidak aktif,dan reaksi siswa terhadap stimulus yang diberikan guru mencapai $47 \%$ dengan kategori tidak aktif sehingga persentase motivasi belajar siswa mencapai $49 \%$ pada saat peneliti mengadakan observasi motivasi masih belum aktif. Hasil belajar siswa pun menjadi rendah yaitu mencapai 50\% atau 18 siswa yang tuntas.

Desain penelitian dalam penelitian ini adalah PTK dengan berkolaborasi dengan guru yang ditetapkan 2 siklus. Dalam PTK ada 4 tahapan yaitu perencanaan, tindakan, observasi dan refleksi. Data primer dengan menggunakan tes ulangan dan observasi dengan di checklist, dan data sekunder dengan wawancara. Peneliti menggunakan keharusan nilai sasaran atau KKM (Kriteria Ketuntasan Minimal) menentukan kriteria sukses untuk menganalisis data

Berdasarkan hasil penelitian penerapan model pembelajaran quantum teaching dapat meningkatkan motivasi belajar mencapai $26 \%$ mata pelajaran bahasa Inggris teks penyerta gambar/caption siswa kelas XII AKL2 SMKN 1 Panji semester ganjil tahun ajaran 2019/2020 dan Penerapan model pembelajaran quantum teaching dapat meningkatkan hasil belajar mencapai $22 \%$ mata pelajaran bahasa Inggris teks penyerta gambar/caption siswa kelas XII AKL2 SMKN 1 Panji semester ganjil tahun ajaran 2019/2020
\end{abstract}

Kata Kunci: Model Quantum Teaching, Motivasi, Hasil Belajar

\section{PENDAHULUAN}

Model pembelajaran yang kurang menarik minat siswa akan menyebabkan motivasi belajar siswa rendah dan hasil belajar siswa kurang maksimal. Hasil observasi kelas XII AKL2 SMK Negeri 1 Panji bahwa motivasi belajar minat dan 
perhatian siswa terhadap pelajaran mencapai $49 \%$ dengan kategori tidak aktif, tanggung jawab siswa dalam mengerjakan tugas-tugas belajarnya mencapai 55\% dengan kategori tidak aktif,dan reaksi siswa terhadap stimulus yang diberikan guru mencapai $47 \%$ dengan kategori tidak aktif sehingga persentase motivasi belajar siswa mencapai $49 \%$ pada saat peneliti mengadakan observasi motivasi masih belum aktif. Hasil belajar siswa pun menjadi rendah yaitu mencapai $50 \%$ atau 18 siswa yang tuntas.

Padahal sebaiknya peserta didik menjadi "deep learner processor", yaitu peserta didik dituntut mengerti dan paham akan materi yang disampaikan, karena dengan mengerti secara tuntas peserta didik secara otomatis akan dapat merumuskan definisi dan pengertian yang dimaksud. (Utomo et al., 2017) Aspek pembelajaran berbagai bidang studi, khususnya bidang studi bahasa Inggris di lembaga pendidikan formal terbukti selalu kurang memuaskan berbagai pihak termasuk siswa.

\section{METODE DAN PROSEDUR PENELITIAN}

\section{Rancangan Penelitian}

Penelitian ini adalah penelitian tindakan kelas (PTK). Empat fase dalam satu siklus sebuah PTK seperti ditunjukkan dengan gambar berikut:






\section{Penelitian tindakan Model Kemmis dan Taggart}

Sesuai dengan gambar spiral penelitian tindakan kelas diatas penelitian ini terdiri atas empat fase yaitu perencanaan, tindakan, observasi dan refleksi.

\section{Perencanaan}

Tahap ini merupakan tahap merencanakan segala sesuatu yang akan dilakukan dalam penelitian. Kegiatan yang dilakukan dalam tahap perencanaan ini adalah sebagai berikut:

1. Menyusun rencana pembelajaran pada pokok bahasan yang akan dibahas

2. Mempersiapkan gambar dan perlengkapan dalam pokok bahasan yang akan dibahas

3. Mempersiapkan soal sebagai bahan diskusi baik diluar kelas maupun didalam kelas

4. Mempersiapkan soal tes ulangan harian untuk siswa

5. Mempersiapkan tugas pekerjaan rumah untuk siswa

6. Mempersiapkan rangkuman materi untuk dibagikan kepada siswa

7. Proses belajar mengajar dibagi menjadi tiga tahap yaitu:

a. Pendahuluan, guru memberikan apersepsi tentang pentingnya pembelajaran

Bahasa Inggris yang akan dibahas

b. Kegiatan inti, guru mendampingi dan membimbing siswa dalam melakukan kegiatan Model pembelajaran quantum teaching.

c. Kegiatan penutup

8. Mempersiapkan daftar pertanyaan untuk mewawancarai siswa mengenai tanggapannya terhadap penerapan Model pembelajaran quantum teaching.

9. Membuat lembar observasi yang digunakan peneliti untuk mengamati hasil belajar siswa.

\section{Tindakan}

Pada tahap ini kegiatan yang dilaksanakan adalah melakukan tindakan berdasarkan pada perencanaan yang telah dibuat. Peneliti bertindak sebagai guru. Penelitian ini dilakukan dalam dua siklus dengan rincian sebagai berikut: 


\section{Kegiatan Setiap Siklus}

1. Kegiatan pendahuluan

Guru memberikan apersepsi kepada siswa sesuai dengan materi yang akan dibahas

2. Kegiatan Inti

Langkah-langkah pembelajaran kuantum terdiri dari tanamkan, alami, namai, demonstrasikan, ulangi dan rayakan atau dikenal dengan singkatan TANDUR

a. Tumbuhkan

Konsep tumbuhkan ini sebagai konsep operasional dari prinsip "bawalah dunia mereka ke dunia kita”. Dengan usaha menyertakan siswa dalam pikiran dan emosinya, sehingga tercipta jalinan dan kepemilikan bersama atau kemampuan saling memahami. Secara umum konsep tumbuhkan adalah sertakan diri mereka, pikat mereka, puaskan keingintahuan, buatlah siswa tertarik atau penasaraan tentang materi yang akan diajarkan. Dari hal tersebut tersirat, bahwa dalam pendahuluan (persiapan) pembelajaran dimulai guru seyogyanya menumbuhkan sikap positif dengan menciptakan lingkungan yang positif, lingkungan sosial (komunitas belajar), sarana belajar, serta tujuan yang jelas dan memberikan makna pada siswa, sehingga menimbulkan rasa ingin tahu.

b. Alami

Tahap ini jika kita tulis pada rencana pelaksanaan pembelajaran terdapat pada kegiatan inti. Konsep "alami" mengandung pengertian bahwa dalam pembelajaran guru harus memberi pengalaman dan manfaat terhadap pengetahuan yang dibangun siswa sehingga menimbulkan hasrat alami otak untuk menjelajah. Pada konsep alami guru memberikan cara terbaik agar siswa memahami informasi, memberikan permainan atau kegiatan yang memanfaatkan pengetahuan yang sudah mereka miliki, sehingga dapat memfasilitasi siswa untuk memperoleh pengetahuan yang melekat.

c. Namai

Konsep ini berada pada kegiatan inti, yang "namai" mengandung maksud bahwa penamaan memuaskan hasrat alami otak (membuat siswa 
penasaran, penuh pertanyaan mengenai pengalaman) untuk memberikan identitas, menguatkan dan mendefinisikan. Penamaan dalam hal ini adalah mengajarkan konsep, melatih keterampilan berpikir dan strategi belajar. Pertanyaan yang dapat memandu guru dalam memahami konsep "namai" yaitu perbedaan yang perlu dibuat dalam belajar, apa yang harus guru tambahkan pada pengertian siswa, strategi kiat jitu, alat berpikir yang digunakan untuk siswa ketahui atau siswa gunakan.

d. Demonstrasikan

Tahap ini masih pada kegiatan inti, pada tahap ini adalah memberi kesempatan siswa untuk menunjukkan bahwa siswa tahu. Hal ini sekaligus memberi kesempatan siswa untuk menunjukkan tingkat pemahaman terhadap materi yang dipelajari. Strategi yang dapat digunakan adalah mempraktekkan, melakukan percobaan, menyusun laporan, menganalisis data, melakukan gerakan tangan, kaki, gerakan tubuh bersama secara harmonis, dan lain-lain.

e. Ulangi

Tahap ini jika kita tuangkan pada rencana pelaksanaan pembelajaran terdapat pada penutup. Tahap ini dilaksanakan untuk memperkuat koneksi saraf dan menumbuhkan rasa "aku tahu bahwa aku tahu ini”. Kegiatan ini dilakukan secara multimodalitas dan multikecerdasan. Guru memberikan ulangan tentang apa yang sudah dipelajari, strategi untuk mengimplementasikan yaitu bisa dengan membuat isian "aku tahu bahwa aku tahu ini" hal ini merupakan kesempatan siswa untuk mengajarkan pengetahuan baru kepada orang lain (kelompok lain), atau dapat melakukan pertanyaan pertanyaan post tes.

f. Rayakan

Tahap ini dituangkan pada penutup pembelajaran. Dengan maksud memberikan rasa puas, untuk menghormati usaha, ketekunan, dan kesusksesan yang akhirnya memberikan rasa kepuasan dan kegembiraan. Dengan kondisi akhir siswa yang senang maka akan menimbulkan kegairahan siswa dalam belajar lebih lanjut.

3. Kegiatan penutup 
Guru memberikan tugas pelajaran rumah melalui LKS, pemberian tugas melalui LKS dimaksudkan untuk menyeimbangkan pengetahuan. Siswa yang telah didapat melalui diskusi dalam pembelajaran model pembelajaran quantum teaching.

\section{Metode Analisa Data}

Untuk mengkategorikan tingkah laku siswa selama pelaksanaan tindakan, peneliti menggunakan lembar observasi berdasarkan Sukarni (2001:429) tentang aspek yang harus diamati dalam penggunaan Model Pembelajaran Model pembelajaran quantum teaching Untuk mengetahui prosentase Minat dan Perhatian Siswa Terhadap Pelajaran, Tanggung Jawab Siswa Dalam Mengerjakan Tugas-Tugas Belajarnya dan Reaksi Siswa Terhadap Stimulus Yang Diberikan Guru.

Sedangkan untuk mengukur ketuntasan dalam belajar siswa dapat menggunakan rumus

$$
\mathrm{P}=\frac{n}{N} x 100 \%
$$

Keterangan $\mathrm{P}=$ Prosentase ketuntasan

$\mathrm{n}=$ Jumlah siswa yang tuntas

N= Jumlah seluruh siswa (Depdiknas, 2004:14-17)

Setelah nilai hasil belajar dipresentasikan kemudian dicari standar ketuntasan ini didasarkan pada standar yang ditetapkan oleh sekolah tersebut yaitu daya serap siswa secara individu dan klasikal standar tersebut yaitu:

Daya serap perseorangan

Seorang siswa dikatakan telah memenuhi KKM bila mencapai $\geq 75 \%$ atau nilai $\geq 75$.

Daya serap klasikal

Suatu kelas dikatakan telah memenuhi standar ketuntasan belajar di kelas tersebut telah mencapai $\geq 85 \%$ dari jumlah siswa yang telah mencapai nilai $\geq 75$. (Kurikulum dari SMK Negeri 1 Panji Situbondo)

Untuk menghitung jumlah skor digunakan pedoman sebagai berikut:

$$
\mathrm{P}=\frac{N}{M} \times 100 \%
$$

Keterangan: $\mathrm{P}$ : Persentase 
$\mathrm{N}$ : Skor yang diperoleh peserta didik

M: Skor maksimal

Kategori Penilaian Keaktifan dan Kriteria Hasil Peserta Didik Secara Individual

\begin{tabular}{|c|c|}
\hline Prosentase & Kriteria \\
\hline $\mathrm{P} \geq 80$ & Sangat aktif \\
$70 \leq \mathrm{P}<80$ & Aktif \\
$60 \leq \mathrm{P}<70$ & Cukup aktif \\
$\mathrm{P}<60$ & Tidak aktif \\
& \\
\hline
\end{tabular}

\begin{tabular}{|c|c|}
\hline Rentangan Skor & Kategori Hasil Belajar \\
\hline $80-100$ & Sangat Baik \\
$70-79$ & Baik \\
$60-69$ & Cukup Baik \\
$50-59$ & Kurang Baik \\
$0-49$ & Sangat Kurang Baik \\
\hline
\end{tabular}

Sumber: Ningtiash (2007)

\section{HASIL PENELITIAN DAN PEMBAHASAN}

Melihat hasil pengamatan pada saat proses pembelajaran gambar teknik yang sudah dilakukan, maka observer bersama guru mendiskusikan tentang perubahan metode pembelajaran dan strategi yang digunakan dalam menyampaikan materi ajar yang dirasa mampu membuat siswa menjadi lebih aktif dan kreatif Adapun hasil observasi aktivitas peneliti yang dilakukan pada tanggal 31 Oktober 2019 di kelas XII AKL2 dengan materi pelajaran yang berbeda dengan peneliti dapat dilihat pada tabel berikut:

Hasil observasi Motivasi belajar Siswa Prasiklus

\begin{tabular}{|c|c|c|}
\hline Kategori Aktivitas & Frekuensi (F) & Persentase \% \\
\hline Sangat Aktif & 3 & $9 \%$ \\
\hline Aktif & 1 & $3 \%$ \\
\hline Cukup Aktif & 16 & $44 \%$ \\
\hline Kurang Aktif & 16 & $44 \%$ \\
\hline Sangat Kurang Aktif & 0 & 0 \\
\hline Jumlah & 36 & $100 \%$ \\
\hline
\end{tabular}

Ketuntasan belajar siswa kelas XII AKL2-A Prasiklus

\begin{tabular}{|l|c|c|}
\hline Kategori Hasil Belajar & Frekuensi (F) & Persentase (\%) \\
\hline Sangat baik & 4 & $11 \%$ \\
\hline
\end{tabular}




\begin{tabular}{|l|c|c|}
\hline Baik & 9 & $25 \%$ \\
\hline Cukup Baik & 23 & $64 \%$ \\
\hline Kurang Baik & 0 & $0 \%$ \\
\hline Sangat Kurang Baik & 0 & $0 \%$ \\
\hline Jumlah & 36 & 100 \\
\hline
\end{tabular}

Berdasarkan hasil prasiklus masih di bawah KKM yang ditetapkan oleh sekolah sehingga guru perlu memberikan model pembelajaran siswa yang mampu melibatkan siswa dalam pembelajaran yaitu Metode quantum teaching

Siswa masih kurang mampu memiliki minat maka perlu adanya model pembelajaran yang mampu mengatasi kesulitan belajar siswa khususnya siswa kelas XII AKL2. Usaha yang dilakukan guru adalah telah menyediakan bacaan yang membuat siswa menarik dengan memberikan gambar namun tidak berhasil siswa kurang terlibat langsung dalam pembelajaran bahkan dalam mengerjakan soal masih cenderung mencontek hasil pekerjan teman. Berdasarkan latar belakang itulah peneliti memiliki inisiatif untuk menerapkan Metode quantum teaching yang mampu memberikan pemahaman dalam membaca dan ketelitian dalam membaca soal dengan memberikan garis dan merangkum suatu materi yang dianggap sulit serta memberikan kesempatan kepada siswa untuk lebih aktif dalam kelas tanpa adanya bimbingan guru.

Kegiatan observasi sampai pelajaran selesai untuk mengamati motivasi belajar siswa dan aktivitas guru selam proses belajar mengajar berlangsung. Hasil observasi aktivitas siswa dapat dilihat pada tabel berikut:

Hasil observasi Motivasi belajar Siswa Siklus 1

\begin{tabular}{|c|c|c|}
\hline Kategori Aktivitas & Frekuensi (F) & Persentase \% \\
\hline Sangat Aktif & 10 & $30 \%$ \\
\hline Aktif & 11 & $28 \%$ \\
\hline Cukup Aktif & 15 & $42 \%$ \\
\hline Kurang Aktif & 0 & 0 \\
\hline Sangat Kurang Aktif & 0 & 0 \\
\hline Jumlah & 36 & $100 \%$ \\
\hline
\end{tabular}

Tidak hanya siswa saja dalam penelitian ini disalahkan, namun guru kurang mampu memberikan motivasi kepada siswa sehingga banyak siswa kurang 
percaya diri dengan hasil jawaban yang dikerjakan sendiri, sehingga banyak yang terjadi pada saat pembelajaran antara lain siswa banyak yang menyontek hasil pekerjaan teman dan bahkan ada siswa yang membawa catatan kecil untuk menjawab soal yang diberikan guru. Maka untuk memperbaiki hal tersebut membutuhkan suatu perbaikan pada siklus berikutnya dengan memperbaiki pada kegiatan ini pada siklus 2. Berdasarkan hasil observasi yang peneliti lakukan terhadap aktivitas guru selama pelaksanaan tindakan pada siklus I, dalam menerapkan metode quantum teachingbahwa guru sudah dapat menerapkan metode quantum teachingsesuai dengan prosedur dan langkah-langkahnya. Namun pada saat proses pengelompokan dan pengaturan kelompok siswa masih ramai dan terlihat kurang teratur, sehingga banyak menyita waktu pelajaran. Guru juga belum maksimal dalam memberikan pengakuan atau penghargaan terhadap siswa yang telah melakukan motivasi belajarnya dengan baik. Guru masih terkesan kaku dan kurang menguasai metode quantum teaching sehingga perlu adanya perbaikan untuk meningkatkan hasil belajar siswa jika dibandingkan pada prasiklus yang hanya peningkatan sebesar $22 \%$ siswa yang tuntas pada siklus pertama.

Berdasarkan hasil observasi aktivitas siswa, hasil tes dan wawancara dapat disimpulkan bahwa perlu adanya perbaikan pembelajaran pada siklus II terutama karena hasil ternyata belum mencapai ketuntasan secara klasikal, sehingga dapat disimpulkan bahwa pada siklus I kurang berhasil. Oleh karena itu perlu adanya tindakan perbaikan dan penyempurnaan yang mengacu pada kekurangan dan halhal yang belum terlaksana pada siklus I, sehingga lebih dapat optimal dan sempurna lagi. Agar dapat mewujudkan hal tersebut, peneliti dan guru memutuskan untuk melaksanakan siklus berikutnya yaitu siklus II.

Ketuntasan belajar siswa kelas XII AKL2-A Siklus 1

\begin{tabular}{|l|c|c|}
\hline Kategori Hasil Belajar & Frekuensi (F) & Persentase (\%) \\
\hline Sangat baik & 16 & $44 \%$ \\
\hline Baik & 20 & $56 \%$ \\
\hline Cukup Baik & 0 & $0 \%$ \\
\hline Kurang Baik & 0 & $3 \%$ \\
\hline Sangat Kurang Baik & 0 & $0 \%$ \\
\hline
\end{tabular}




\begin{tabular}{|l|c|c|}
\hline Jumlah & 36 & 100 \\
\hline
\end{tabular}

Kegiatan observasi sampai pelajaran selesai untuk mengamati motivasi belajar siswa dan aktivitas guru selama proses belajar mengajar berlangsung.

Hasil observasi Motivasi belajar Siswa Siklus 2

\begin{tabular}{|c|c|c|}
\hline Kategori Aktivitas & Frekuensi (F) & Persentase \% \\
\hline Sangat Aktif & 30 & $83 \%$ \\
\hline Aktif & 6 & $17 \%$ \\
\hline Cukup Aktif & 0 & $0 \%$ \\
\hline Kurang Aktif & 0 & $0 \%$ \\
\hline Sangat Kurang Aktif & 0 & $\%$ \\
\hline Jumlah & 36 & $100 \%$ \\
\hline
\end{tabular}

Hasl ini disebabkan oleh guru memberikan kesempatan kepada siswa untuk membaca materi selama 10 menit akan mendukung siswa untuk menjadi lebih paham pada saat guru menjelaskan sehingga tidak ada siswa yang akan merasa kebingungan pada saat guru menjelaskan. Selain itu pula dengan melibatkan siswa dalam kelompok belajar akan lebih memberikan kesempatan untuk siswa ain bersama kelompoknya berbagi tentang pengetahuan yang siswa peroleh dari kegiatan membaca, sehingga hanya terdapat 2 siswa saja tang kurang interaktif dengan Metode quantum teaching. Membaca dan memahami materi sudah mencapai persentase $92 \%$ dengan kategori sangat aktif disebabkan siswa diberikan kesempatan oleh siswa yang pandai sehingga siswa mampu memahami materi baik dari penjelasan guru maupun penjelasan dari teman yang berada dalam kelompok. Kegiatan pada indikator ketiga bahwa menulis rangkuman berdasarkan dari kesimpulan yang telah diuraikan oleh siswa sehingga persentase keaktifan siswa mencapai $82 \%$ dengan kategori sangat aktif.

Hasil observasi terhadap guru dalam pembelajaran bahasa Inggrisdengan Metode quantum teaching sudah mengacu pada tahap-tahap pembelajaran dengan menggunakan metode quantum teaching, kekurangan pada siklus I seperti kondisi kelas yang ramai dan ketidaktepatan alokasi waktu sudah dapat teratasi dengan baik. Guru sudah sangat menguasai teknik pembelajaran dengan menggunakan metode quantum teaching dan peningkatan lain pada proses membimbing dan berkeliling kelas, langkah ini sudah dilaksanakan dengan berkeliling kelas sehingga semua siswa berkesempatan melaporkan hasil diskusi mereka atau menanyakan hal-hal yang belum dipahami. Guru mengajar dengan sesuai rencana pembelajaran dan sesuai dengan waktu yang direncanakan. Berpedoman pada 
indikator aktivitas guru mengajar, maka guru dalam penerapan pembelajaran dengan menggunakan metode quantum teaching dapat dikategorikan baik dan sesuai dengan yang diharapkan peneliti.

Berdasarkan observasi yang dilakukan setelah penerapan metode quantum teaching, hasil belajar siswa mengalami peningkatan. Kegiatan prasiklus mencapai persentase $45 \%$ dengan kategori tidak aktif kemudian diadakan siklus pertama mencapai persentase 65\% dengan kategori cukup aktif kemudian diadakan siklus 2 meningkat $19 \%$ sehingga mencapai persentase $84 \%$ dengan kategori sangat aktif.

Peningkatan motivasi belajar siswa menunjukkan bahwa metode quantum teaching dapat dipertimbangkan sebagai pendekatan pembelajaran yang baik diterapkan pada mata pelajaran bahasa Inggris yang sangat berkaitan dengan kehidupan sehari-hari. Tanggapan guru mengenai penerapan metode quantum teaching sangat mendukung pembelajaran ini, karena guru dapat memperbaiki proses pembelajaran yang telah dilaksanakan dengan lebih efektif dan efisien.

Berdasarkan hasil penelitian dan pembahasan dapat disimpulkan bahwa penerapan metode quantum teaching dapat meningkatkan hasil belajar dan keaktifan siswa di kelas XII AKL2 di SMK Negeri 1 Panji Situbondo. Peningkatan keaktifan siswa dapat dilihat dari hasil observasi yang dilakukan pada saat pembelajaran bahasa Inggrisberlangsung, sedangkan peningkatan hasil belajar dapat diketahui dari nilai ulangan harian siswa.

Keunggulan pembelajaran dengan menggunakan metode quantum teaching pada penerapannya yang melibatkan siswa secara aktif dalam proses belajar mengajar dan mendorong siswa untuk memperoleh pengetahuannya sendiri tanpa selalu tergantung pada guru, meningkatkan konsentrasi dan pengetahuan siswa melalui pembelajaran yang bersifat auditori dan visual. Serta menumbuhkan kreatifitas siswa dalam berfikir, saling bertukar pikiran, mampu mengemukakan ide-ide atau pendapat yang sesuai dengan wawancara yang berkaitan dengan materi yang dibahas dan melatih siswa untuk lebih aktif dalam bertanya dan menjawab pertanyaan-pertanyaan baik dari guru maupun dari siswa lain.

Dengan adanya metode quantum teaching ini siswa terdorong untuk memahami cepat dengan teks penyerta gambar/caption. Kelemahan metode 
quantum teaching adalah guru cenderung kesulitan dalam pengelolaan kelas dan waktu.

\section{KESIMPULAN}

Berdasarkan hasil penelitian dan pembahasan pada bab IV dapat disimpulkan sebagai berikut: Penerapan model pembelajaran quantum teaching dapat meningkatkan motivasi belajar mencapai $26 \%$ mata pelajaran bahasa Inggris teks penyerta gambar/caption siswa kelas XII AKL2 SMKN 1 Panji semester ganjil tahun ajaran 2019/2020. Penerapan model pembelajaran quantum teaching dapat meningkatkan hasil belajar mencapai $22 \%$ mata pelajaran bahasa Inggris teks penyerta gambar/caption siswa kelas XII AKL2 SMKN 1 Panji semester ganjil tahun ajaran 2019/2020.

Berdasarkan pada kesimpulan di atas, maka kami menyarankan khususnya kepada. Bagi guru, sebagai alternatif model pembelajaran untuk meningkatkan kualitas proses belajar mengajar : Bagi Kepala Sekolah, yang terkait, agar hasil penelitian ini dapat dijadikan masukan positif dalam rangka peningkatan mutu pendidikan. Bagi Pengawas, penelitian ini memberikan pengalaman yang sangat berharga dalam rangka mengembangkan pengetahuan.Bagi peneliti lain, diharapkan agar penelitian tindakan kelas ini dapat berguna untuk dijadikan acuan dalam penelitian selanjutnya 


\section{DAFTAR PUSTAKA}

Arikunto, 2006. Penelitian Tindakan Kelas. Yogyakarta: Bumi Aksara.

Beck, K. L., Jones, B., Ullah, I., McNaughton, S. A., Haslett, S. J., \& Stonehouse, W. 2018. Associations between dietary patterns, socio-demographic factors and anthropometric measurements in adult New Zealanders: an analysis of data from the 2008/09 New Zealand Adult Nutrition Survey. European journal of nutrition, 57(4), 1421-1433.

Bolatto, A. D., Wong, T., Utomo, D., Blitz, L., Vogel, S. N., Sánchez, S. F., ... \& Walter, F. 2017. The EDGE-CALIFA Survey: Interferometric Observations of 126 Galaxies with CARMA. The Astrophysical Journal, 846(2), 159.

Dimyati dan Mudjiono, 2000. Belajar dan Pembelajaran. Jakarta : Rineka Karya.

Hamdayana, J. 2014. Creative and Character Learning Models and Methods. Bogor Ghalia Indonesia.

Harjanto, 2017. Proses Belajar Mengajar. Jakarta. Rineka Cipta

Hidayat, A., \& Machali, I. 2012. Pengelolaan pendidikan: konsep, prinsip, dan aplikasi dalam mengelola sekolah dan madrasah.

Isnaini, M., Wigati, I., \& Oktari, R. 2016. Pengaruh Penggunaan Media Pembelajaran Torso Terhadap Hasil Belajar Siswa pada Materi Sistem Pencernaan pada Manusia di SMP Negeri 19 Palembang. Jurnal Biota, 2(1), 82-91.

Kosasih, N., \& Sumarna, D. 2013. Pembelajaran Quantum dan Optimalisasi Kecerdasan. Bandung: Alfabeta.

Nana Sudjana, 2015. Penilaian Hasil Proses Belajar Mengajar. Bandung: PT. Remaja Rosdakarya

Ningtiash, 2007. Pengembangan Kurikulum dan Pembelajaran Matematika. Malang: Universitas Negeri Malang

Nuryana, A., \& Purwanto, S. 2010. Efektivitas brain gym dalam meningkatkan konsentrasi belajar pada anak. Indigenous: Jurnal Ilmiah Psikologi, 12(1).

Ramadhani, M. I., \& Ayriza, Y. (2019). The effectiveness of quantum teaching learning model on improving the critical thinking skills and the social 
science concept understanding of the elementary school students. Jurnal Prima Edukasia, 7(1), 47-57.

Santosa, A. S. E., Santyadiputra, G. S., ST, M. C., \& Divayana, D. G. H. (2017). Pengembangan e-modul berbasis model pembelajaran problem based learning pada mata pelajaran administrasi jaringan kelas XII teknik komputer dan jaringan di SMK TI Bali global Singaraja. KARMAPATI (Kumpulan Artikel Mahasiswa Pendidikan Teknik Informatika), 6(1), 6272.

Sudjana, N. 2009. Penilaian Hasil Belajar Mengajar.Bandung: Remaja Rosdakarya.

Suhaenah Suparno, 2001. Dasar-dasar Ilmu Pendidikan, Jakarta: PT, Raja Grafindo Persada

Sukarni, 2001. Dasar-Dasar Ilmu Pendidikan. Jogjakarta: ArRuzz Media

Sumarna, A. 2013. Perubahan Pemahaman Konsep Siswa SMA Kelas XI Berdasarkan Gender Pada Materi Hidrolisis Garam Dengan Menggunakan Teks Perubahan Konseptual (Doctoral dissertation, Universitas Pendidikan Indonesia).

Uzer Usman, 2017. Guru Profesional. Al-Falah: Jurnal Ilmiah Keislaman dan Kemasyarakatan, 17(2), 274-285.

Wena, M. 2009. Strategi pembelajaran inovatif kontemporer suatu tinjauan konseptual operasional. Jakarta: bumi aksara. 